\title{
17: 74487656-74478932
}

National Cancer Institute

\section{Source}

National Cancer Institute. 17: 74487656-74478932. NCI Thesaurus. Code C45049.

Physical location of LGALS3BP_Gene 